\title{
Farmer Suicides: Consequences and Coping Mechanism in the Deceased Families
}

\author{
B. Rajani ${ }^{1^{*}}$, I. Sreenivasa Rao ${ }^{2}$, M. Sreenivasulu ${ }^{3}$ and K.B. Suneetha Devi ${ }^{4}$ \\ ${ }^{1}$ Department of Agricultural Extension, College of Agriculture, PJTS Agricultural University, \\ Rajendranagar, Hyderabad, Telangana, India \\ ${ }^{2}$ Extension Education Institute, PJTSAU, Rajendranagar, Hyderabad, Telangana, India \\ ${ }^{3}$ Department of Agricultural Extension, College of Agriculture, PJTSAU, Rajendranagar, \\ Hyderabad, Telangana, India \\ ${ }^{4}$ Department of Agronomy, College of Agriculture, Jagityal, Telangana, India \\ *Corresponding author
}

\begin{tabular}{|l|}
\hline K e y w or d s \\
$\begin{array}{l}\text { Farmer suicide, Deceased } \\
\text { farmer, Consequences of } \\
\text { farmer suicides, Coping } \\
\text { mechanism }\end{array}$ \\
\hline Article Info \\
\hline $\begin{array}{l}\text { Accepted: } \\
\text { 10 July 2018 } \\
\text { Available Online: } \\
10 \text { August } 2018\end{array}$ \\
\hline \hline
\end{tabular}

\section{Introduction}

India was earlier known as the golden bird, there was no lack of food and money in the country, and the farmers were on the whole happy. That is also the reason why India has been known as an agriculture-based nation.
The present research study was carried out with an exploratory design of social research. As Telangana state stands in second position in occurrence of farmer suicides in India, Telangana state was purposively selected for the study. In the state, Warangal and Karimnagar districts were selected purposively based on highest number of suicides. From each district 50 deceased families were selected randomly and the data was collected from deceased families by conducting detailed interview and through Focussed Group Discussion with public representatives, progressive farmers, neighbours and extension personnel in the study area. Findings of the study revealed that the negative consequences faced by the deceased farmer families after the suicides were lack of financial help/aid, pressure of repayment of loan, converted to agriculture labour, left agriculture, severe mental stress etc. Further the positive consequences include continuing the agriculture by the spouses or children, received widow pension and compensation. The coping mechanisms followed by the families of deceased farmer were Social assistance from villagers/ neighbours/ relatives, Converted to labour, Borrowing from money lenders, Reducing daily and marriage expenses, Migration to metros for work, Land sold out, Stopped education of children etc. Other motivating factors that gave a push to move on with life were receiving compensation and widow pension, love for children, sole responsibility of the family, active involvement in the family and faith in god. 
has already begun and on the other side increased input costs while reducing yields and profits. It is significant that the count of farmers taking their lives is rising even as the numbers of farmers diminishes, that is, on a shrinking farmer base. As much as 3.8 million hectare area of agricultural land holding was diminished in India between the two agricultural censuses of 1995-96 and 2010-11. About 3,02,116 Indian farmers have taken their lives since 1995 to 2014 concentrated in Maharashtra, Madhya Pradesh, Andhra Pradesh, Karnataka and Chhattisgarh. This occurred at an average of 46 farmer's suicides a day (Sainath 2015).

Telangana stands in the second position in number of farmers' suicides in the country (NCRB, 2014 and 2015). Higher level of farmer suicides is ascribed to cotton cultivation and continuous drought. All India Debit and Investment Survey 2013 revealed that incidence of indebtedness was alarming in Telangana with $74 \%$ which is in top rank in the country. About 1194 number of farmers' suicides were reported in newly formed Telangana State from 2.6.2014 to 29.3.2016, out of which Warangal district occupies first place followed by Karimnagar (Department of Agriculture, 2016). This research paper deals with various consequences faced by the deceased farmer families after the suicides and the coping mechanism among deceased farmer families after the suicides.

\section{Materials and Methods}

The present research study was carried out with an exploratory design of social research. As Telangana state stands in second position in occurrence of farmer suicides in India, Telangana state was purposively selected for the study. In the state, two erstwhile districts Warangal and Karimnagar were selected purposively based on highest number of suicides. A total of 100 deceased families @
50 deceased families from each district pertaining to the years 2014 to 2016 were selected randomly from the list obtained from the Department of Agriculture, Telangana state. Data were collected from the selected respondents by using the interview schedule. A structural interview schedule was developed in consultation with subject matter specialists of concerned area. Observation of respondent's background, behaviour, emotions, feelings, ideas, aspirations and surroundings were also made use of during interview. Further data were collected through focussed group discussion with relatives of the deceased farmer, neighbours, public representatives, progressive farmers, extension personnel wherever necessary.

\section{Results and Discussion}

\section{Consequences}

Consequences operationally defined as the changes that occurred within the family after suicidal death of deceased farmer in due course of time. The changes occurred within family have been ascertained. The study has identified various severe consequences or changes that occurred after suicide of the deceased within the family and are recognized and perceived by family members (Table 1).

About 49 per cent of the households continuing agriculture either in their own land or practicing agriculture in tenant land. Most of the deceased households left agriculture either by selling the land $(8 \%)$ or by giving land for tenancy $(21 \%)$ to others like close relatives, neighbouring farmers etc. Lands were sold and cleared the loan as much as possible due to inability to pay back high interest loans. Because of lack of irrigation facility, 13 per cent of households kept their land barren. Tenant farming households accounting to 9 per cent left agriculture as they cannot bear the cost of cultivation 
including tenancy rate. Few (4\%) households sold their gold, livestock and bullock cart to clear the loans and get rid of debt burden.

Overnight the members of the deceased households (deceased wife/ mother/ son/ daughter-in-law) were translated into agricultural labourers (55\%) and also nonagricultural labourers (24\%) i.e. beedi making, NREGS works, stitching, sweeper and cooking at schools for mid-day meals, helper at builder, mason, gas delivery boy, running small kirana shop and hotel to raise money to sustain their family including the burden of paying back the debts. About 11 per cent of the deceased families migrated to metros for earning by doing different jobs/ works.

Suicide has further increased the gender oppression and bias, now the women are not only dominated by the family or community but also by the other social categories such as moneylenders. About 58 per cent are facing pressure from moneylenders for repayment of loan with interest. Most of the households didn't know about indebtedness before suicide of the deceased, but only after death only came to know about debt situation. Even there were few $(1 \%)$ instances of suicide by the other members of the family. This reflects the extreme agrarian crisis. Children lost both parents to suicide. Further in few (9\%) instances, the other members of the family died due to mental stress.

In over (19\%) of deceased households, poor economic condition compelled their children to stop the education and go for wage earning for sharing the livelihood expenditure of family. For girls, they thought about getting them married as soon as possible and for boys, they thought about getting work for them, because for the next generation agriculture is not working out. So, more and more people are stepping out of agriculture. The deceased household are continuing primary education of children as there is provision of free education and few got free admission into Navodaya or Gurukul schools and few shifted from private schools to government schools. Few households continuing their children's higher education with an intention of good future for their children.

About 5 per cent of the households faced huge expenditure for the treatment of the suicide attempted deceased to save their life before death. They brought loan with high interest and this became additional burden on them. Soon after the death, the married children got separated in about 6 per cent of the households and the widows are living alone and surviving themselves. After sudden suicide by head of family, severe psychological impact was observed on other family members. In majority of deceased households (40\%), severe anxiety and stress was developed about future life, which lead to mental instability. Widows burdened with the new responsibility as the sole breadwinner. Under all these mental stress conditions also, the widows managing to provide for children's' education, daily expenses, medical bills and marriages for their children etc. by selling land or gold or by taking additional loan or by working as labour.

About 59 per cent of the households are worried about the future of the children and old age members of the family. Further 20 per cent are worried about the daughter's marriages. In most of the situations (89\%), the households did not receive any financial help from close relatives, friends or any other in the village. Very few (11\%) widows got help from their parents, siblings, married daughters and from close relatives. About 58 per cent of the deceased households received compensation from government which helped the families a lot by clearing debts to some extent, by doing daughters marriages and as investment for crop cultivation etc. 
Table.1 Distribution of deceased farmers household according to different consequences due to suicide

\begin{tabular}{|l|c|c|}
\hline \multicolumn{1}{|c}{$\begin{array}{c}\text { Consequence } \\
\text { Continuing the agriculture by the spouses or children }\end{array}$} & F & $\%$ \\
\hline Left agriculture & 49 & 49 \\
\hline a. Land tenancy to others & 21 & 21 \\
\hline b. Land sold $\quad$ Left barren & 8 & 8 \\
\hline c. By tenant farmer & 13 & 13 \\
\hline d. $\quad$ & 9 & 9 \\
\hline Other assets sold for livelihood (gold, live stock, bullock cart) & 4 & 4 \\
\hline Converted to Agriculture labour & 55 & 55 \\
\hline Converted to Non- Agriculture labour & 24 & 24 \\
\hline Migration to metros for work (Warangal, Hyderabad, Mumbai, Dubai) & 11 & 11 \\
\hline Pressure of repayment of loan & 58 & 58 \\
\hline Lost elder person in family & 9 & 9 \\
\hline Stopped education of children & 9 & 9 \\
\hline Anxiety about the marriage of daughter/daughters and delayed marriages & 20 & 20 \\
\hline Severe mental stress & 40 & 40 \\
\hline Worried about the future of children and old age members of family & 59 & 59 \\
\hline Suicide by the other members of the family & 1 & 1 \\
\hline Lack of financial help/aid & 89 & 89 \\
\hline Spouse living alone & 6 & 6 \\
\hline Heavy medical expenditure after attempting suicide before death & 5 & 5 \\
\hline Compensation received & 58 & 58 \\
\hline Widow pension received & 89 & 89 \\
\hline Multiple response & & \\
\hline
\end{tabular}

* Multiple responses

Table.2 Distribution of deceased farmers household according to different coping mechanisms after suicide

\begin{tabular}{|l|c|c|}
\hline \multicolumn{1}{|c}{ Coping Mechanism } & \multicolumn{2}{c|}{ (N=100) } \\
\hline Savings of family & $\mathbf{F}$ & \multicolumn{1}{|c|}{} \\
\hline Land sold out & 7 & 8 \\
\hline Other assets sold out & 4 & 4 \\
\hline Borrowing from money lenders & 76 & 76 \\
\hline Stopped education of children & 9 & 9 \\
\hline Converted to labour & 79 & 79 \\
\hline Migration to metros for work & 11 & 11 \\
\hline Joining children in Navodaya/ Gurukul schools on free of cost & 5 & 5 \\
\hline Social assistance from villagers/ neighbours/ relatives & 97 & 97 \\
\hline Help from close relatives/ friends & 11 & 11 \\
\hline Reducing daily expenses & 22 & 22 \\
\hline Reducing marriage expenses & 14 & 14 \\
\hline Compensation received from Government & 58 & 58 \\
\hline Widow pension received & 89 & 89 \\
\hline Love for children & 86 & 86 \\
\hline Sole responsibility of the family & 65 & 65 \\
\hline Active involvement in the family & 95 & 95 \\
\hline Faith in God & 44 & 44 \\
\hline
\end{tabular}


Almost all $(100 \%)$ of the widows are getting widow pensions from the government monthly which are been utilized for daily expenses.

In the social sense, women continue to be dependent, and are not the decision makers unless under dire situations such as a husband committing suicide. Otherwise, decisions around the land, how to run a land, whom to lease it out to and other things are not taken by the women. So, women farmers are struggling with such issues.

\section{Coping mechanism}

Coping mechanism operationally defined as the motivating factor that gives a push in moving on with life by the families of the deceased farmers.

In general, savings of the family are the most widely used coping mechanism, but have a more limited role for deceased farmer families, hence rely more on their assets. Very few $(1 \%)$ deceased families rely on savings, 8 per cent of the families sold their agriculture land and 4 per cent of the families sold other assets like gold, livestock and bullock carts for their survival. The common coping strategy in the study area was increasing work either agriculture related or non-agriculture related works or migration of selected household members. Majority (79\%) of the deceased families converted to agricultural labourer or non-agricultural labourer or both.

Few (11\%) families migrated to metros in search of employment. Few (5\%) households joined their children in Navodaya/ Gurukul schools on free of cost with the assistance of public representatives and friends (Table 2).

About $97 \%$ of the deceased families receiving social assistance from villages/ neighbours/ relatives and was most often informal and was the most prevalent coping mechanism among households headed by women. Few (11\%) households receiving assistance from friends and family. 76 per cent of the households borrowing required amount from money lenders to move on with life. Further reducing overall consumption like stopping of education (9\%), reducing the daily expenses $(22 \%)$, marriage expenses $(14 \%)$. Received assistance from the government in the form of compensation $(58 \%)$ and widow pension $(89 \%)$ are the important coping mechanisms which helps the deceased households to the maximum. The increased responsibility for the widowed person increased the sense of frustration and it propelled them to become innovative in finding means of survival.

Further love for children (86\%), sole responsibility of the family $(65 \%)$, active involvement in the family $(95 \%)$ and faith in God $(44 \%)$ were also some of the coping mechanisms followed by deceased households in the study area.

\section{Acknowledgements}

I express my profound gratitude to my Major Advisor Dr. I. Sreenivasa Rao for inspiring support, perpetual guidance, suggestions, sharing his truthful and illuminating views and I am thankful to my minor guides Dr M. Sreenivasulu, Dr K.B. Suneetha Devi for their kind suggestions, encouragement. I thank all my teachers, friends, university and Department of Agriculture for their cooperation and help during the research programme.

\section{References}

Department of Agriculture. 2016. Statement showing the details of farmers' suicides in the state of Telangana from 02-062014 to 29-03-2016. Telangana, Hyderabad. 
NCRB. 2014. Distribution of Suicides by Profession-2014 (State \& UT wise). http://www.ncrb.gov.in/StatPublications /ADSI/ADSI2014/table-2.7.pdf

NCRB. 2015. Profession - wise Distribution of Suicides during 2015 (State \& UT wise).

http://ncrb.gov.in/StatPublications/ADS I/ADSI2015/table-2A.1.pdf

http://www.indiacelebrating.com/article/articl e-on-farmers-suicides/

Kale, N.M., Mankar, D. M. and Wankhade, P.P.2014. Consequences of Farmers
Suicide and Suggestions Perceived from Victim's Households to Prevent Suicides in Vidarbha Region. Global Journal of Science Frontier Research: $D$ Agriculture and Veterinary. 14(10): 43-46

Sainath. P. 2013. Farmers' suicide rates soar above the rest. The Hindu. 18.05.2013. http://www.thehindu.com/opinion/colu $\mathrm{mns} / \mathrm{sainath} /$ farmers-suicide-rates-soarabove-the-rest/article4725101.ece Agricultural censuses. 1995-96 and 2010-11. http://agcensus.dacnet.nic.in/

\section{How to cite this article:}

Rajani, B., I. Sreenivasa Rao, M. Sreenivasulu and Suneetha Devi, K.B. 2018. Farmer Suicides: Consequences and Coping Mechanism in the Deceased Families. Int.J.Curr.Microbiol.App.Sci. 7(08): 1560-1565. doi: https://doi.org/10.20546/ijcmas.2018.708.178 